\title{
A POSTERIOR MEDIASTINAL DERMOID TUMOUR WITH MARKED ANATOMICAL DIFFERENTIATION
}

In a review of the literature between 1940 and 1950 inclusive we have found records of 79 mediastinal dermoid tumours. Six of these were posterior, a proportion of approximately $8 \%$. One of them was malignant and one contained teeth. The records of these six "posterior" mediastinal teratomas are summarized in Table I. The case reported here adds another to this list.

TABLE I

POSTERIOR" MEDIASTINAL TERATOMAS DESCRIBED IN THE LITERATURE $1940-50$

\begin{tabular}{|c|c|c|c|c|c|}
\hline Author & Sex & Age & Size (cm.) & Symptoms & Pathology \\
\hline $\begin{array}{l}\text { Pannier and } \\
\text { Daems } \\
(1949)\end{array}$ & M. & 35 & Not stated & $\begin{array}{l}\text { Kypho- } \\
\text { scoliosis }\end{array}$ & $\begin{array}{l}\text { Osseous and } \\
\text { cartilaginous } \\
\text { laminae }\end{array}$ \\
\hline Lloyd (1948) & F. & 16 & $9 \times 5$ & Pain & $\begin{array}{l}\text { Teratoma; } \\
\text { thymus } \\
\text { present }\end{array}$ \\
\hline $\begin{array}{c}\text { Friedrich } \\
\text { (1942) }\end{array}$ & F. & 21 & $20 \times 18 \times$ & $\begin{array}{l}\text { Slight } \\
\text { dyspnoea, } \\
\text { intense } \\
\text { pain }\end{array}$ & $\begin{array}{l}\text { Dermal, plain } \\
\text { muscle } \\
\text { present }\end{array}$ \\
\hline $\begin{array}{l}\text { Dybicki and } \\
\text { Jakubowski } \\
\text { (1950) }\end{array}$ & M. & 25 & $\begin{array}{r}6.5 \times 7 \\
\times 7.5\end{array}$ & $\begin{array}{l}\text { Asympto- } \\
\text { matic }\end{array}$ & $\begin{array}{l}\text { Dermal, bone } \\
\text { and teeth }\end{array}$ \\
\hline $\begin{array}{l}\text { Danis and } \\
\text { Govaerts } \\
\text { (1942) }\end{array}$ & M. & 12 & "Orange" & - & Dermoid \\
\hline $\begin{array}{l}\text { Bradford, } \\
\text { Mahon, and } \\
\text { Grow (1947) }\end{array}$ & M. & 23 & $\begin{array}{c}8.5 \times 9.5 \\
\times 7.5\end{array}$ & $\begin{array}{c}\text { Sarcomatous } \\
\text { metastases } \\
\text { after } \\
\text { operation }\end{array}$ & $\underset{\text { teratoma }}{\text { Malignant }}$ \\
\hline
\end{tabular}

\section{CASE Report}

A boy, aged 18 in 1950, felt pain in the right side of the chest posteriorly on bending his back. The pain was moderate in degree but had persisted for about two years. In 1948 a clinical examination had shown marked kypho-scoliosis.

In 1950 he attended voluntarily a mass miniature radiography survey, and chest films (Figs. 1 and 2) in June, 1950, showed an opacity situated on the right posteriorly in a concavity formed by the fifth to the tenth dorsal vertebrae. In this opacity there were 14 teeth arranged in a cone with their apices pointing centrally. Their roots were set in a calcified domeshaped structure (Fig. 3).

At operation in June, 1950, the tumour was found closely attached to the dorsal vertebrae and to the aorta. Four intercostal arteries and two intercostal veins were divided where they appeared to go into the tumour wall. There was also a vascular pedicle originating in an undetermined manner near the right main bronchus. A firm mass of extrapleural fat lay lateral to the oesophagus and along the azygos vein. The tumour was opened in several places during the dissection, when fatty fluid, caseous material, and hair escaped.

Convalescence was uneventful. There was no change in the kypho-scoliosis a year and a half later.

The excised tumour measured $13 \times 7 \times 6 \mathrm{~cm}$. and weighed $320 \mathrm{~g}$. It was covered externally by a fibrous capsule, rough over the area of attachment to the vertebrae but smooth in relation to the lung; there were some deposits of fat in the latter surface. When the capsule was incised and everted a hollow tubular skin pedicle $4 \mathrm{~cm}$. in diameter was seen to connect the capsule to a central teratomatous mass, which was divided into two main parts. One part consisted of an osseo-cartilaginous dome in which were located 14 teeth in various stages of eruption. The other part consisted of fleshy structures related to the pedicle. The most striking fleshy structure was a tongue, $5 \mathrm{~cm}$. long and $4 \mathrm{~cm}$. wide at its base (Fig. 4). Less clearly defined structures included half an upper and lower lip with characteristic colour and form, a palpebral fissure with slit, cartilage plates, and vibrissae, and a chin-like protuberance. Inside the skin pedicle was a smoothly lined space extending from the chin to the capsule, containing a hollow cuboidal bone fixed to the base of the dome. Within the pedicle were also a grey mass of brain tissue $1.5 \mathrm{~cm}$. high and a strawberry-like mass of choroid plexus $1 \mathrm{~cm}$. in diameter.

Histological examination confirmed or determined the nature of the structures described above. There were no malignant changes.

The teeth included perfectly formed incisors, premolars, and molars, and possibly a canine. The films and specimen were examined by Mr. W. B. Grandison, F.D.S., who classified the teeth as being probably: 7.6.5.4.0.2.1. (1.2.3.) 4.5.5.6.0.8., the group in brackets being anterior teeth of uncertain classification, and the "double five" possibly representing a supernumerary tooth. There were no teeth of the first dentition, although a few detached crowns in relation to the premolar groups might represent the remains 
Fig. 1.-Postero-anterior radiograph of the chest showing the dermoid tumour on the right.

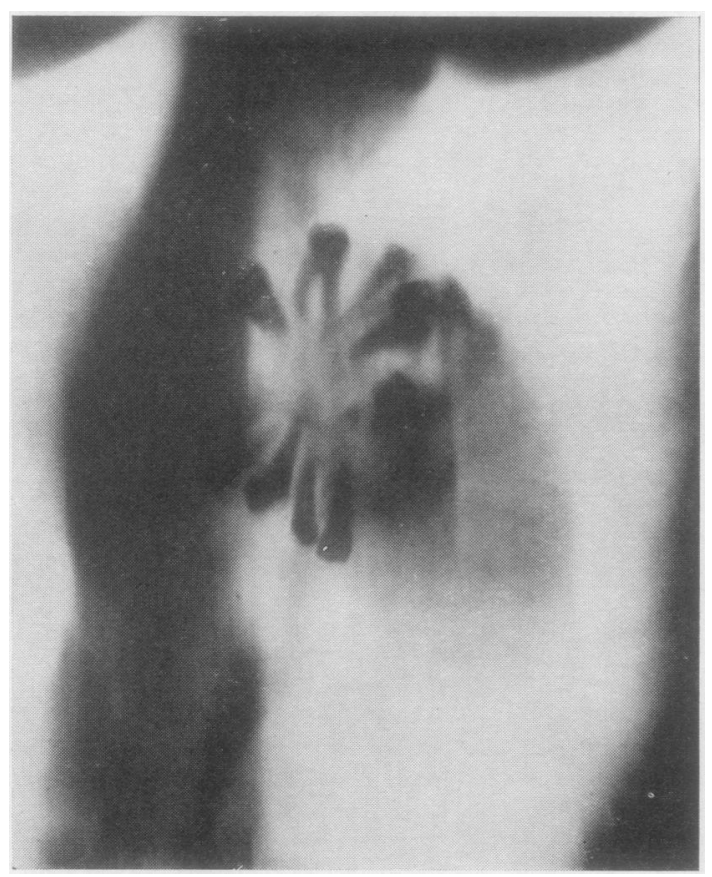

Fig. 3.-Lateral tomogram of the dermoid tumour.

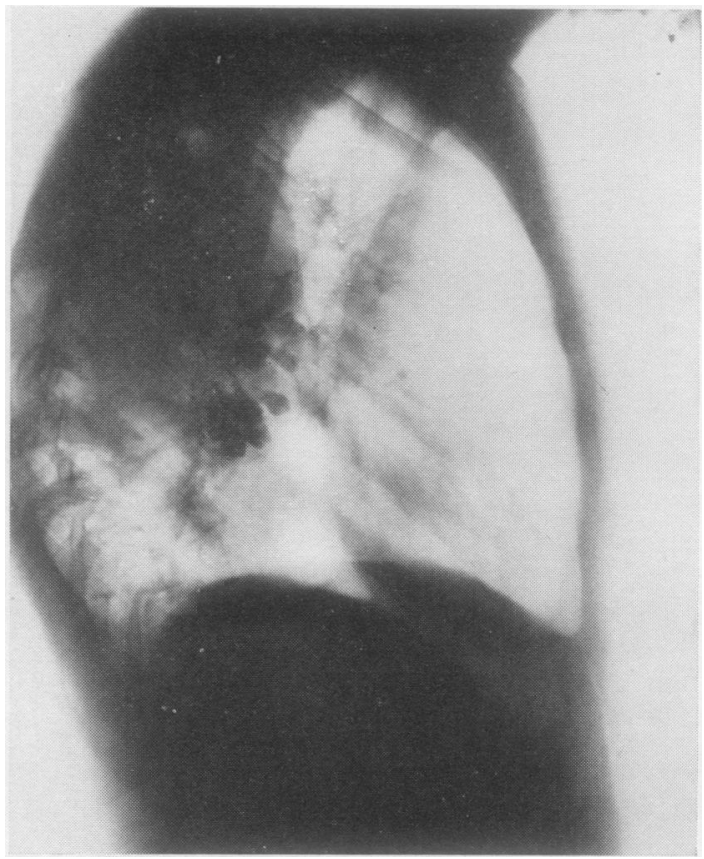

FIG. 2.-Right lateral radiograph of the chest showing the posterior dermoid tumour.

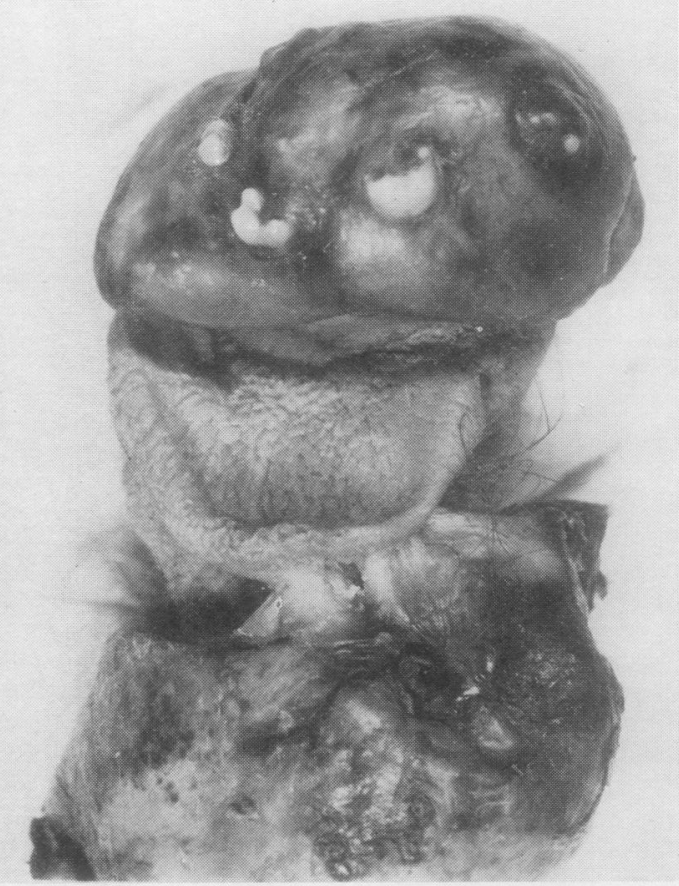

FIG. 4.-Photograph showing the osseo-cartilaginous dome and teeth at the top, adult tongue in the middle, and the everted capsule below. 
of partially absorbed temporary teeth. The roots of the permanent teeth were fully formed. The age of the wisdom teeth was considered not less than 17 years. All were upper teeth.

\section{SUMMARY}

A posterior mediastinal teratomatous dermoid with exceptional anatomical differentiation is described. All its structures may be described as " head parts," hence the tumour probably arose from a group of misplaced cephalo-potential embryonic cells. There were no malignant changes.

\section{REFERENCES}

Bradford, M. L., Mahon, H. W., and Grow, J. B. (1947). Surg. Ginec. Obstet., 85, 647.

Danis, R., and Govaerts, J. (1942). Bull. Acad. Méd. Belg., 7, 424. Dybicki, J., and Jakubowski, A. (1950). Pol. Tyg. lek., 5, 661. Friedrich, R. (1942). Zbl. Chir., 69, 479.

Lloyd, M. S. (1948). Dis. Chest, 14, 396.

Pannier, R., and Daems, J. (1949). Acta tuberc. belg., 40, 352. 